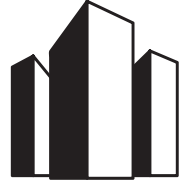

УДК 351.86

\title{
Специфіка етапів інституалізації розвідувальної діяльності в системі забезпечення національної безпеки України
}

\author{
В. А. Соколов \\ Національна академія державного управління при Президентові України, \\ Київ, Украӥна
}

doi: $10.15421 / 15201734$

Визначено поняття «інституалізація розвідувальної діяльності в системі забезпечення національної безпеки». Виявлено, що з метою реалізації державної політики національної безпеки України одним із завдань є удосконалення державної системи стратегічного планування, створення єдиної системи моніторингу, аналізу, прогнозування та прийняття рішень у сфері національної безпеки і оборони, забезпечення ефективної координації та функціонування єдиної системи ситуаційних центрів профільних органів державної влади сектору безпеки і оборони. Виокремлено та розкрито специфіку етапів інституалізації розвідувальної діяльності в системі забезпечення національної безпеки України, а саме: усвідомлення потреби в аналітичній та розвідувальній інформації; формування мети розвідувальної діяльності та цілей розвідувально-інформаційного забезпечення; ціннісне і нормативне впорядкування розвідувальної діяльності в інтересах забезпечення національної безпеки; організація розвідувальної діяльності в інтересах забезпечення національної безпеки. Наголошено, що основною умовою існування будь-якої суверенної держави є захист її національних інтересів та забезпечення державної та воєнної безпеки держави. Охарактеризовано сфери розвідувальної діяльності розвідувальних органів України, зокрема: політична, економічна, військова, науково-технічна, прикордонна, інформаційна та екологічна.

Ключові слова: аналітична діяльність; оперативно-розшукова діяльність; розвідувальна інформація; розвідувально-інформаційне забезпечення; сфери розвідувальної діяльності; політики національної безпеки; національні інтереси; воєнна безпека держави

\section{Specificity of institutionalization stages for reconnaissance activity in the system of Ukrainian national security's guaranteeing}

\section{A. Sokolov}

The National academy for public administration under the President of Ukraine, Kyiv, Ukraine

The author's definition of the notion "institutionalization of reconnaissance activity in the system of national security's guaranteeing" is suggested in the article. The specificities of institutionalization stages for reconnaissance activity in the system of Ukrainian national security's guaranteeing are marked out and developed here. For example, the study defines such options as need in recognition of analytical and reconnaissance information; forming of the aim for reconnaissance activity as well as goals of reconnaissanceinformation providing; value and legal ordering of reconnaissance activity in the interests of national security's guaranteeing; organization of reconnaissance activity in the interests of national security's guaranteeing.

Consequently, the recognition stage of analytical and reconnaissance information characterizes by the fact that since the first days of public and military construction in Ukraine was set a course towards its scientific support and creation of the system on reconnaissance-information providing of the national security policy. That's why in official as well as in scientific discourse the main aim of reconnaissance activity is formulated as overcoming of indefiniteness in the situation of unavoidable choice between alternatives of public-administrative decisions in the sphere of Ukrainian national security. Moreover, the general aims of reconnaissance-information providing in scientific discourse are defined as monitoring of strategic risks in different branches.

Цитування даної статті: Соколов В. А. Специфіка етапів інституалізації розвідувальної діяльності в системі забезпечення національної безпеки України / В. А. Соколов // Аспекти публічного управління. 2017. - T.5. - №10. - C. 51- 59.

Citation of this article: Sokolov, V.A. Cpetsyfika etapiv instytualizatsii rozviduvalnoi diialnosti v systemi zabezpechennia natsionalnoi bezpeky Ukrainy [Specificity of the stages of institutionalization of intelligence activitiesin the system of ensuring national security of Ukraine]. Public administration aspects, 5(10), 51-59.

Received: 04.10 .2017

Accepted: 18.10 .2017 
Nowadays all activities of reconnaissance bodies in Ukraine are ordered in many respects, but the most considerable for our study are value and legal ones. Such trends are indicated by currently in forced national legislation, which regulates the matters of reconnaissance-information providing of Ukrainian national security policy. Benefit of the given study is revelation of the circumstance that in order to implement Ukrainian state military policy properly compulsory are improvement of the state's strategic planning system, creation of the common system of monitoring, analysis, prognostication and decision-making in the sphere of national security and defense, guaranteeing of effective coordination and functioning of the common system of situational centers in profile public authorities in security and defense branch.

As a result, institutional mechanism of reconnaissance-information providing for public policy concerning Ukrainian national security includes structurally the wide range of authorities that organize and realize monitoring and analysis of the state's security environment in the context of reaching the aims defined in the Strategy of national security of Ukraine.

Keywords: analytical activity; investigation and search operations; reconnaissance information; reconnaissance-information providing; spheres of reconnaissance activity; national security policy; national interests; military security of the state

\title{
Специфика этапов институализации разведывательной деятельности в системе обеспечения национальной безопасности Украины
}

\author{
В. А. Соколов
}

Национальная академия государственного управления при Президенте Украины, Киев, Украина

Определено понятие «институализация разведывательной деятельности в системе обеспечения национальной безопасности». Установлено, что в целях реализации государственной политики национальной безопасности Украины одной из задач является совершенствование государственной системы стратегического планирования, создания единой системы мониторинга, анализа, прогнозирования и принятия решений в сфере национальной безопасности и обороны, обеспечения эффективной координации и функционирования единой системы ситуационных центров профильных органов государственной власти сектора безопасности и обороны. Выделена и раскрыта специфика этапов институализации разведывательной деятельности в системе обеспечения национальной безопасности Украины, а именно: осознание потребности в аналитической и разведывательной информации; формирование цели разведывательной деятельности и целей разведывательно-информационного обеспечения; ценностное и нормативное упорядочение разведывательной деятельности в интересах обеспечения национальной безопасности; организация разведывательной деятельности в интересах обеспечения национальной безопасности. Отмечено, что основным условием существования любого суверенного государства является защита ее национальных интересов и обеспечения государственной и военной безопасности государства. Охарактеризованы сферы разведывательной деятельности разведывательных органов Украины, в частности: политическая, экономическая, военная, научно-техническая, пограничная, информационная и экологическая.

Ключевые слова: аналитическая деятельность; оперативно-розыскная деятельность; разведывательная информация; разведывательно-информационное обеспечение; сферы разведывательной деятельности; политики национальной безопасности; национальные интересы; военная безопасность государства

Постановка проблеми. У Стратегії національної безпеки України зазначено, що докорінні зміни у зовнішньому та внутрішньому безпековому середовищі України обумовлюють необхідність створення ефективного сектору безпеки і оборони України. Недосконалість правового, інституційного та науково-методичного забезпечення діяльності розвідувальних органів гальмує не лише створення ефективного сектору безпеки і оборони України, а й успішну реалізацію «Стратегії реформ - 2020»
[8]. 3 метою реалізації вказаного напряму державної політики національної безпеки України одним із завдань є вдосконалення державної системи стратегічного планування, створення єдиної системи моніторингу, аналізу, прогнозування та прийняття рішень у сфері національної безпеки і оборони, забезпечення ефективної координації та функціонування єдиної системи ситуаційних центрів профільних органів державної влади сектору безпеки і оборони [5]. 
Аналіз літературних джерел свідчить про те, що розгляду проблем теорії та практики розвідувально-інформаційного забезпечення державної політики національної безпеки України присвячено наукові праці вітчизняних дослідників, а саме: А. Семенченка (дав загальну характеристику системи інформаційно-аналітичного забезпечення політики національної безпеки України) [9]; В. Федька [11], Л. Артюшина, Г. Костенка [1], В. Чорного [12] (узагальнили та систематизували зарубіжний та вітчизняний досвід діяльності розвідувальних органів); В. Пилипчука (визначив пріоритетні напрями дослідження новітньої історії органів безпеки та розвідки в контексті розвитку системи забезпечення національної безпеки України) [4], М. Шевченка (увів у науковий обіг поняття «механізм інформаційно-розвідувального забезпечення політики національної безпеки») [13].

Незважаючи на значний науковий доробок вітчизняних дослідників, маємо констатувати, що сьогодні ще обмаль праць, у яких би обгрунтовувалися пропозиції щодо визначення: 1) актуальних викликів і загроз у сучасних умовах та на віддалену перспективу; 2) напрямів розвитку органів розвідки та системи забезпечення національної безпеки України в умовах трансформацій простору безпеки тощо.

Тобто недостатне дослідження новітньої історії державного управління системою розвідувально-інформаційного забезпечення політики національної безпеки України, зокрема становлення, розвитку і правового забезпечення діяльності розвідувальних органів, не сприяє всебічній науковій оцінці наявних здобутків і прорахунків, а також розробці пропозицій щодо подальшого розвитку системи забезпечення національної безпеки України в контексті завдань реформування сектору безпеки i оборони.

Пошуку відповідей на вказані та інші проблеми, на нашу думку, сприятиме дослідження новітньої історії державного управління системою розвідувально-інформаційного забезпечення політики національної безпеки України.

Метою статті $\epsilon$ розкриття специфіки етапів інституалізації розвідувальної діяль- ності в системі забезпечення національної безпеки України.

Виклад основного матеріалу. А. А. Васіна інституалізацію у державному управлінні (англ. institualization in state management) пропонує розуміти як процес формування, розвитку i засвоєння всіма елементами системи державного управління норм, правил, ролей, цінностей і еталонів, необхідних для здійснення державно-управлінської діяльності, способів контролю за їх поведінкою, а також результат процесу, у межах якого досягаються об'єктивізація державного управління і його ефективне функціонування. Процес інституалізації у державному управлінні включає кілька послідовних етапів: 1) виникнення потреби, задоволення якої вимагає спільних організаційних дій за участю державних інституцій; 2) формування загальних цілей; 3) встановлення процедур розробки й прийняття норм і правил; 4) розробка, прийняття, запровадження норм і правил; 5) встановлення системи санкцій для підтримки норм і правил, диференціація ї застосування в окремих випадках; 6) формування статусів і ролей, які б охоплювали всіх учасників певної державноуправлінської діяльності; 7) легітимізація, суспільне визнання встановлених правил і норм; 8) закріплення цього визнання в неформальних правилах, традиціях поведінки та взаємодії всіх учасників державноуправлінської діяльності [2, с. 202 - 204].

Застосуємо наведені вище теоретичні положення під час дослідження практичних проблем інституалізації розвідувальної діяльності в системі забезпечення національної безпеки. Останнє пропонуємо розуміти як процес становлення стратегічної та ситуаційної аналітики як соціального інституту, що включає в себе етапи:

1. Усвідомлення потреби в аналітичній та розвідувальній інформації. Основною умовою існування будь-якої суверенної держави $\epsilon$ захист іï національних інтересів. Водночас першопорядковою умовою успішного державного будівництва $є$ забезпечення державної та воєнної безпеки держави. Останнє потребує:

1) вирішення найважливіших завдань державної безпеки та налагодження інформаційно-аналітичного забезпечення по- 
літики національної безпеки. 3 метою вирішення вказаних завдань 20 вересня 1991 p. Верховна Рада України ухвалила Постанову «Про створення Служби національної безпеки України» [7]. Протягом вересня 1991 р. - лютого 1992 р. призначено керівництво Служби національної безпеки України та головних структурних підрозділів, розроблена і затверджена організаційно-штатна структура апарату служби, ii регіональних підрозділів. Також створені Головне управління розвідки, Головне управління контррозвідки, Управління «К», а також регіональні управління [10]. Важливими кроками у справі зміцнення організаційно-правових засад забезпечення державної безпеки та налагодження інформаційно-аналітичного забезпечення політики національної безпеки стали ухвалені українським парламентом у 1992 р. Закон України «Про Службу безпеки України» [3, c. 275 - 287] та Закон України «Про оборону України» [3, с. $72-86]$;

2) створення спеціальної системи розвідувально-інформаційного забезпечення центрального апарату міністерства оборони та державно-управлінських структур виконавчої гілки влади. Головним елементом вказаної системи $є$ військова розвідка. На думку начальника Головного управління розвідки Міністерства оборони України (1992 - 1997 рр.) О. Скіпальського: «В основу організації і діяльності військової розвідки повинні бути покладені основні положення Воєнної доктрини і об'єктивний принцип незалежності результатів інформаційної роботи від зміни політичних поглядів вищого керівництва держави» [11, с. 385].

3) відповідного наукового супроводу. Першою повнокровною структурою наукового супроводження військового будівництва став Центр оперативно-стратегічних досліджень Збройних сил України. Цей центр структурно входив до складу Центрального апарату Міністерства оборони України та виконував дві функції - управлінську та дослідницьку. Також 20 листопада 1991 р. міністр оборони України схвалив склад Наукової експертної ради Міністерства оборони як офіційного органу незалежної експертизи. На думку вітчизняних дослідників Л. Артюшина та Г. Костенка:
«Наявність науково проробленої і юридично закріпленої концептуальної основи дозволила Україні першій, у межах колишнього Радянського Союзу, підготувати і вже 6 грудня 1991 р. прийняти основні закони України щодо військового будівництва: «Про Збройні Сили України» і «Про оборону України». За рядом своїх розділів ці закони не мали аналогів на теренах колишнього СРСР» [1, с. 11].

2. Формування мети розвідувальної діяльності та цілей розвідувально-інформаційного забезпечення. Розглянемо визначення цілей розвідувальної діяльності у вітчизняному офіційному та науковому дискурсах.

В офіційному дискурсі, а саме в ст. 24 Закону України «Про Службу безпеки України» (1992 р.) одним з основних завдань служби $\epsilon$ здійснення інформаційно-аналітичної роботи в інтересах ефективного проведення органами державної влади та управління України внутрішньої і зовнішньої діяльності, вирішення проблем оборони, соціально-економічного будівництва, науково-технічного прогресу, екології та інших питань, пов'язаних 3 національною безпекою України [3, с. 281]. Також у ст. 11 та 12 Закону України «Про оборону України» (1992р.) визначено функції Міністерства оборони України та Генерального штабу Збройних сил України щодо розвідувально-інформаційного забезпечення, а саме: 1) на Міністерство оборони України покладено виконання функції 3 проведення розвідувальної та інформаційно-аналітичної діяльності в інтересах національної безпеки та оборони держави, у прийнятті участі в аналізі воєнно-політичної обстановки, прогнозуванні, виявленні та визначенні рівня воєнної загрози національній безпеці; 2) на Генеральний штаб Збройних сил України покладено виконання функції з проведення розвідувальної та інформаційно-аналітичної діяльності в інтересах підтримання в готовності і бойового застосування Збройних сил України [3, с. 77 - 81]. Проте лише в ст. 1 Закону України «Про розвідувальні органи України» (2001р.) в офіційному дискурсі визначено поняття «розвідувальна діяльність»: «діяльність, яка здійснюється спеціальними засобами і методами 3 метою забезпечення визначених законом органів 
державної влади розвідувальною інформацією, сприяння та реалізації та захисту національних інтересів, протидії за межами України зовнішнім загрозам національній безпеці України». У цій самій статті визначено поняття «розвідувальна інформація»: «усні та зафіксовані на матеріальних носіях (у тому числі у зразках виробів і речовин) відомості, які неможливо отримати офіційним шляхом, про реальні та потенційні можливості, плани, наміри і дії іноземних держав, організацій та окремих осіб, що загрожують національним інтересам України, а також про події і обставини, що стосуються національної безпеки і оборони» [3, c. 288].

У ст. 6 Закону України «Про розвідувальні органи України» визначено сфери розвідувальної діяльності розвідувальних органів України, а саме:

- Служба зовнішньої розвідки України - у політичній, економічній, військовотехнічній, науково-технічній, інформаційній та екологічній сферах;

- розвідувальний орган Міністерства оборони України - у воєнній, воєнно-політичній, воєнно-технічній, воєнно-економічній, інформаційній та екологічній сферах;

- розвідувальний орган спеціально уповноваженого центрального органу виконавчої влади у справах охорони державного кордону - у сферах прикордонної та імміграційної політики, а також в інших сфеpax, що стосуються питань захисту державного кордону України та іiі суверенних прав у виключній (морській) економічній зоні [3, c. 290].

E сенс також зауважити, що згідно зі ст. 2 Закону України «Про Державну прикордонну службу України» (2003 р.) однією 3 функцій Державної прикордонної служби України визначено ведення розвідувальної, інформаційно-аналітичної та оперативнорозшукової діяльності в інтересах забезпечення захисту державного кордону України згідно із законами України «Про розвідувальні органи України» та «Оперативнорозшукову діяльність» [3, с. 438].

Розглянемо визначення цілей розвідувальної діяльності у вітчизняному науковому дискурсі. Так, на думку О. Скіпальського, головною метою військової розвідки є своєчасне попередження керівників держав- них органів про виникнення загрози національній безпеці шляхом надання керівництву держави і збройним силам своєчасної, достовірної та повної інформації про діяльність інших держав, які можуть становити загрозу національній безпеці держави. Ця мета досягається шляхом відповідного розвідувально-інформаційного забезпечення. Останнє О. Скіпальський пропонує розуміти як комплекс заходів, спрямованих на добування військовою розвідкою даних як воєнного, так і воєнно-політичного, воєнно-економічного, воєнно-технічного і воєнно-наукового характеру, необхідних для зацікавлених споживачів відповідних державних структур [11, с. 386].

На думку Л. Артюшина та Г. Костенка, метою розвідувальної діяльності $\epsilon$ моніторинг стратегічного ризику. Останне науковці пропонують розуміти як процедуру комплексного збирання інформації, іiі нагромадження, аналіз, оцінювання та прогнозування стратегічного ризику 3 метою керування ним. Моніторинг стратегічного ризику повинен здійснюватися на таких рівнях управління системами безпеки: національному, регіональному, субрегіональному, глобальному. При цьому напрямами аналізу стратегічного ризику мають бути: дії тільки національних урядів і взаємодіючих із ними суб'єктів політичної і економічної діяльності; дії національних урядів, суб'єктів економічної діяльності, політичних сил усередині держави i за ії межами (партій, урядів у вигнанні і под.) [1, с. 17].

3. Ціннісне і нормативне впорядкування розвідувальної діяльності в інтересах забезпечення національної безпеки. У Законі України «Про Раду національної безпеки і оборони України» (1998 р.) вказано, що до компетенцій Ради національної безпеки i оборони України належить забезпечення i контроль надходження та опрацювання необхідної інформації, іiі збереження, конфіденційність та використання в інтересах національної безпеки України, аналіз на їі основі стану і тенденції розвитку подій, що відбуваються в Україні і світі, визначення потенційних та реальних загроз національним інтересам України [3, с. 108 - 112]. Інформаційно-аналітичне та організаційне забезпечення діяльності Ради національної безпеки і оборони України здійснює їі 
апарат, який підпорядковується секретареві Ради національної безпеки і оборони України.

Для опрацювання i комплексного вирішення проблем міжгалузевого характеру, забезпечення науково-аналітичного та прогнозного супроводження діяльності Ради національної безпеки і оборони України за iii рішенням у межах коштів, передбачених Державним бюджетом України, можуть утворюватися тимчасові міжвідомчі комісії, робочі та консультативні органи. Функції та повноваження цих органів визначаються окремими положеннями, які затверджує президент України.

В Законі України «Про розвідувальні органи України», який схвалила Верховна Рада України у березні 2001 р., чітко визначено мету, головні завдання та принципи роботи, правові засади організації та діяльності розвідувальних органів. Так, у ст. 4 цього закону на розвідувальні органи України покладається виконання таких завдань:

добування, аналітична обробка та надання визначеним законом органам державної влади розвідувальної інформації;

- здійснення спеціальних заходів, спрямованих на підтримку національних інтересів і державної політики України в економічній, політичній, воєнній, військово-технічній, екологічній та інформаційній сферах, зміцнення обороноздатності, економічного і науково-технічного розвитку, захисту та охорони державного кордону;

забезпечення безпечного функціонування установ України за кордоном, безпеки співробітників цих установ та членів їх сімей у країні перебування, а також відряджених за кордон громадян України, обізнаних у відомостях, що становлять державну таємницю;

участь у боротьбі 3 тероризмом, міжнародною організованою злочинністю, незаконним обігом наркотичних засобів, незаконною торгівлею зброєю і технологією ii виготовлення, незаконною міграцією в порядку, визначеному законом, незаконним обігом наркотичних засобів, незаконною торгівлею зброєю і технологією іiі виготовлення, незаконною міграцією;

вжиття заходів протидії зовнішнім загрозам національній безпеці України, життю, здоров'ю іiі громадян та об'єктам державної власності за межами України [3, c. 289].

Загальне керівництво, питання утворення, реорганізації і ліквідації розвідувальних органів здійснюються відповідно до конституційних повноважень президентом України [3, с. 32 - 36]. Координує діяльність розвідувальних органів України президент України через очолювану ним Раду національної безпеки і оборони України, яка діє відповідно до Закону України «Про Раду національної безпеки і оборони України» [3, с. $108-112]$.

У ст. 8 Закону України «Про основи національної безпеки України» (2003р.) визначено, що діяльність усіх державних органів повинна бути зосереджена на прогнозуванні, своєчасному виявленні, попередженні й нейтралізації зовнішніх i внутрішніх загроз національній безпеці, захисту суверенітету й територіальної цілісності України, безпеки ії прикордонного простору, підйомі економіки країни, забезпеченні особистої безпеки, конституційних прав і свобод людини й громадянина, викорінюванні злочинності, удосконаленні системи державної влади, зміцненні законності й правопорядку та збереженні соціальнополітичної стабільності суспільства, зміцненні позицій України у світі, підтримці на належному рівні іiї оборонного потенціалу й обороноздатності, радикальному поліпшенні екологічної ситуації [3, с. 55 - 58].

4. Організація розвідувальної діяльності в інтересах забезпечення національної безпеки. Організація розвідувальної діяльності в інтересах забезпечення національної безпеки почала здійснюватися 31992 р. відповідно до положень законів України «Про Службу безпеки України» [3, с. 275 - 287] та «Про оборону України» [3, с. $72-86]$, а також Закону України «Про Державну прикордонну службу України» (2003 р.) [3, с. $437-454]$.

У лютому 2004 р. Указом президента України на базі Головного управління розвідки та Головного управління «Р» був створений Департамент розвідки Служби безпеки України (СБУ). А вже 14 жовтня 2004 р. Указом президента України «Про Службу зовнішньої розвідки України» на базі Департаменту розвідки СБУ була створена Служба зовнішньої розвідки України 
(CBP) як спеціальний державний орган. Вiтчизняний дослідник В. Чорний зазначає: «Поза сумнівом, виділення СВР зі складу СБУ було виправданим. Адже зовнішня розвідка в жодній країні світу не належить до правоохоронних органів. Вона здійснює свою діяльність за межами держави, добуває закриту інформацію, яка не підлягає розголошенню» [12, с. 218]. Далі науковець зазначає, що СВР України була створена не на підставі закону, як того вимагає Конституція України, а Указом президента України. У такому нелегітимному форматі служба проіснувала понад рік і лише після прийняття Закону України «Про Службу зовнішньої розвідки України» в 2005 р. ця суперечність була знята [12, с. 218].

У Законі України «Про Службу зовнішньої розвідки України» однозначно встановлюється, що служба $є$ військовим формуванням, яке підпорядковується президентові України і підконтрольне йому та Верховній Раді України (ст. 1). Також у законі визначено, що СВР України є правонаступником розвідувального органу СБУ (ст. 10) [6]. Усе це свідчить про те, що Україна, сповідуючи загальноєвропейські цінності та стандарти, запровадила в державне управління системою розвідувально-інформаційного забезпечення політики національної безпеки розмежувальний принцип, «відповідно до якого спеціальні служби, що займаються таємною інформаційною діяльністю, відокремлені від останніх, будь-яких зовнішніх владних повноважень» [12, с. 219].

Інформація, здобута й опрацьована розвідувальними органами України, надається президентові України, голові Верховної Ради України, прем'єр-міністрові України та іншим визначеним президентом України споживачам в установленому ним порядку 3 додержанням вимог законів України «Про інформацію» [3, с. 331 - 340], «Про державну таємницю» [3, с. 341 - 363] та ін.

Порядок взаємодії розвідувальних органів України визначається законами і прийнятими відповідно до них іншими нормативно-правовими актами. Розвідувальні органи України взаємодіють встановленим чином 3 органами державної влади України, між собою і з правоохоронними органами України та інформують про свою діяльність громадськість України в установленому порядку. Також розвідувальні органи України 3 дозволу президента України в межах та обсягах, визначених ним, можуть встановлювати і підтримувати контакти зі спеціальними службами іноземних держав, у тому числі на основі двосторонніх чи багатосторонніх міжнародних договорів України 3 додержанням вимог законодавства України [3].

Висновки. Проведений аналіз етапів інституалізації діяльності розвідувальних органів щодо розвідувально-інформаційного забезпечення політики національної безпеки України дозволяє зробити такі висновки:

1) етап усвідомлення потреби в аналітичній та розвідувальній інформації характеризується тим, що з перших днів державного та військового будівництва в Україні був узятий курс на його наукове супроводження та створення системи розвідувально-інформаційного забезпечення політики національної безпеки;

2) як в офіційному, так i в науковому дискурсах основна мета розвідувальної діяльності сформульована як подолання невизначеності в ситуації неминучого вибору варіантів державно-управлінських рішень у сфері національної безпеки України. Загальними цілями розвідувально-інформаційного забезпечення в науковому дискурсі визначено моніторинг стратегічних ризиків у різних сферах;

3) наразі діяльність розвідувальних органів в Україні ціннісно і нормативно впорядкована, про що свідчить чинне національне законодавство, яке регулює питання розвідувально-інформаційного забезпечення політики національної безпеки української держави;

4) інституційний механізм розвідувально-інформаційного забезпечення державної політики національної безпеки України структурно включає в себе комплекс органів, що організовують та проводять моніторинг та аналіз безпекового середовища держави в контексті досягнення цілей, поставлених у Стратегії національної безпеки України. 
1. Артюшин Л. М. Теоретичні аспекти стратегії воєнної безпеки суспільства і держави : монографія / Л. М. Артюшин, Г. Ф. Костенко. - Харків : НУВС, 2003. - 176 с.

2. Васіна А. О. Інституалізація у державному управлінні / А. О. Васіна // Енциклопедія державного управління : у 8 т. / наук.-ред. колегія : Ю. В. Ковбасюк (голова) та ін. - Київ : НАДУ, 2011. - Т. 2 : Методологія державного управління. - С. 202-204.

3. Гриценко А. Нормативно-правова база в галузі безпеки і оборони України / А. Гриценко, М. Кожієл, А. Єрмолаєв, Ф. Флурі. - вид. 2-ге, доповн. - Київ : Центр дослідження армії, конверсії та роззброєння, 2012. $-820 \mathrm{c}$.

4. Пилипчук В. Г. Проблеми дослідження новітньої історії органів безпеки та розвідки в контексті розвитку сектору безпеки України / В. Г. Пилипчук // Стратегічні пріоритети. - 2012. - № 3. - С. $114-119$.

5. Про рішення Ради національної безпеки і оборони України від 6 травня 2015 року «Про Стратегію національної безпеки України» : указ Президента України від 26.05.2015 № 287/2015 // Офіційне інтернет-представництво Президента України. - Режим доступу : http://www.president.gov. ua/documents/2872015-19070.

6. Про Службу зовнішньої розвідки України : закон України від 01.12.2005 // Відомості Верх. Ради України. - 2006. - № 8. - Ст. 94.

7. Про створення Служби національної безпеки України : постанова Верх. Ради України від 20.09.1991 // Відомості Верх. Ради України. - 1991. - № 49. - Ст. 689.

8. Про Стратегію сталого розвитку «Україна - 2020» : указ Президента України від 12.01.2015 № 5/2015 // Офіційне інтернет-представництво Президента України. - Режим доступу : http://www. president.gov.ua/documents/52015-18245.

9. Семенченко А. І. Методологія стратегічного планування у сфері державного управління забезпеченням національної безпеки України : монографія / А. І. Семенченко. - Київ : Вид-во НАДУ, 2008. $-428 \mathrm{c}$.

10. Служба безпеки України: становлення, досвід, пріоритети діяльності. - Київ : НКЦ Ін-т оперативної діяльності та держ. безпеки, 2007. - 192 с.

11. Федько В. Ф. Философия специальных служб: Собрание афоризмов, высказываний и выдержек из оперативных документов / В. Ф. Федько ; вступ. статьи С. М. Худобин, Н. А. Короп, А. А. Запорожец, послесл. В. Н. Большаков. - Киев : Изд. дом «Княгиня Ольга», 2006. - 704 с.

12. Чорний В. С. Військова організація України: становлення та перспективи розвитку : монографія / В. С. Чорний. - Ніжин : ТОВ «Вид-во «Аспект-Поліграф», 2009. - 368 с.

13. Шевченко М. М. Методика системно-комплексного дослідження державного управління забезпеченням національної безпеки / М. М. Шевченко // Вісник Нац. акад. оборони України. - 2010.

- № 4. - C. 235-240.

\section{REFERENCES:}

1. Artiushyn, L.M. \& Kostenko, H.F. (2003). Teoretychni aspekty stratehii voiennoi bezpeky suspilstva $i$ derzhavy : monohrafia [Theoretical aspects of military security's strategy of society and the state. Monograph]. Kharkiv, NUVS (in Ukrainian).

2. Vasina, A.O. (2011). Instytualizatsiia u derzhavnomu upravlinni [Institutionalization in public administration]. Entsyklopediia derzhavnoho upravlinnia: $u \quad 8$ t. (Vol. 2.: Metodolohiia derzhavnoho upravlinnia). 202-204 (in Ukrainian).

3. Hrytsenko, A., Kozhiiel, M., Yermolaiev, A. \& Fluri, F. (2012). Normatyvno-pravova baza v haluzi bezpeky $i$ oborony Ukrainy [Legislation in the field of security and defense of Ukraine]. Kyiv, Tsentr doslidzhennia armii, konversii ta rozzbroiennia. (in Ukrainian). 
4. Pylypchuk, V.H. (2012). Problemy doslidzhennia novitnoi istorii orhaniv bezpeky ta rozvidky v konteksti rozvytku sektoru bezpeky Ukrainy [Research problems of modern history of security and reconnaissance bodies in the context of security branch development in Ukraine]. Stratehichni priorytety, (3), 114-119 (in Ukrainian).

5. The President of Ukraine (2015). The decree "On decision of the Council of national security and defense of Ukraine from 06.05.2015 "On the Strategy of the national security of Ukraine". Retrieved from: http://www.president.gov.ua/documents/2872015-19070 (in Ukrainian).

6. The Verkhovna Rada of Ukraine (2006). The Law of Ukraine "On the Service of external reconnaissance of Ukraine". Vidomosti Verkhovnoi Rady Ukrainy, 8. (in Ukrainian).

7. The Verkhovna Rada of Ukraine (1991). The resolution "On establishment of the Service of national security of Ukraine". Vidomosti Verkhovnoi Rady Ukrainy, 49. (in Ukrainian).

8. The President of Ukraine (2015). The decree "On the Strategy of sustainable development "Ukraine2020”. Retrieved from: http://www.president.gov.ua/ documents/52015-18245 (in Ukrainian).

9. Semenchenko, A.I. (2008). Metodolohiia stratehichnoho planuvannia u sferi derzhavnoho upravlinnia zabezpechenniam natsionalnoi bezpeky Ukrainy: monohrafiia [Methodology of strategic planning in the field of public administration in Ukrainian national security's guaranteeing. Monograph]. NADU, Kyiv (in Ukrainian).

10. Institute of operational activity and state security. (2007). Sluzhba bezpeky Ukrainy: stanovlennia, dosvid, priorytety diialnosti [The Service of security of Ukraine: formation, experience, priorities of activity]. NKT IODDB, Kyiv (in Ukrainian).

11. Fedko, V.F. (2006). Filosofiia spetcialnykh sluzhb: Sobranie aforizmov, vyskazyvanii i vyderzhek iz operativnykh dokumentov [Philosophy of special services. Collection of aphorisms, statements and extracts from operational documents]. Kyiv, Publishing house "Kniaginia Olga" (in Russian).

12. Chornyi, V.S., (2009). Viiskova orhanizatsiia Ukrainy: stanovlennia ta perspektyvy rozvytku : monohrafiia [Military organization of Ukraine: formation and future trends. Monograph]. Nizhyn, Aspekt-Polihraf (in Ukrainian).

13. Shevchenko, M.M. (2010). Metodyka systemno-kompleksnoho doslidzhennia derzhavnoho upravlinnia zabezpechenniam natsionalnoi bezpeky [Methods of system-complex research of public administration in national security's guaranteeing]. Visnyk Natsionalnoi akademii oborony Ukrainy, (4), 235-240 (in Ukrainian).

Соколов Вадим Андрійович - аспірант

Національна академія державного управління при Президентові Украйни Адреса: 03057, Київ, вул. Ежена Потьє, 20

E-mail:vadim_sokolov@ukr.net

Sokolov Vadim A. - postgraduate student

National academy for public administration under President of Ukraine Address: 20, Ezene Pottie Str., Kyiv, 03057, Ukraine

E-mail:vadim sokolov@ukr.net

ORCID 0000-0002-7564-3866 